\title{
Holding Members of Transnational Terrorist Groups Accountable under Article 25 of the Rome Statute: Effectiveness, Legitimacy and Impact
}

\author{
Anna Marie BRENNAN*
}

\begin{abstract}
The International Criminal Court (ICC) has not yet had to consider the application of the Rome Statute to terrorist groups with a network-based organisational structure. This article examines whether members of transnational terrorist groups can be held accountable under Article 25 of the Rome Statute despite their network-based organisational structure. In order for a member of a transnational terrorist group to be held accountable under Article 25 we need to ascertain whether their conduct satisfies the constituent elements of the doctrine of direct and indirect co-perpetration as developed by the Pre-Trial and Trial Chambers in the Lubanga and Katanga cases. Notwithstanding that the doctrine of coperpetration is an attempt to develop an overall theory of accountability at the ICC the concept of control under the doctrine is one-dimensional especially when applied to entities such as transnational terrorist groups which may not have a centralised command in view of their network-based organisational structure. This article will propose that a more inclusive approach to joint perpetration which includes both objective and subjective elements would be more appropriate.
\end{abstract}

Keywords: Transnational terrorist groups - International Criminal Court - Article 25 of the Rome Statute

\section{INTRODUCTION}

Since the aftermath of World War II the principle of individual criminal responsibility has challenged and perplexed international courts and tribunals from the International Military Tribunal (IMT) in Nuremberg to the International Criminal Tribunal for the Former Yugoslavia $\left(\right.$ ICTY ${ }^{\mathrm{I}}$ and the International Criminal Court (ICC). ${ }^{2}$ Indeed, the IMT in Nuremberg held that international crimes can only be "committed by men, not by abstract entities, and only by punishing individuals who commit such crimes can the provisions of international law be enforced." The Nuremberg Principles formulated by the International Law Commission in 1946 further expanded this central tenet by noting that, "complicity in the commission of a crime against peace, a war crime or a crime against humanity [...] is a crime against international law." ${ }^{4}$ However, the application of this principle by the

* Lecturer in Law at the School of Law and Social Justice at the University of Liverpool in the United Kingdom and Irish Research Council Government of Ireland Scholar and PhD Candidate at University College Cork in Ireland. This author would like to thank Professor Siobhan Mullally and Dr Fiona Donson for reading earlier drafts of this article. All errors and omissions are my own. Email: Anna.Marie.Brennan@liverpool.ac.uk.

Statute of the International Tribunal for the Prosecution of Persons Responsible for Serious Violations of International Humanitarian Law Committed in the Territory of the Former Yugoslavia since 1991, SC Res. 827, UN SCOR 48th sess., 32I7th mtg. at I-2 (1993); 32 ILM II59 (1993) (hereinafter ICTY Statute). See also Statute of the International Criminal Tribunal for Rwanda, SC Res. 955, UN SCOR 49th sess., 3453rd mtg, U.N. Doc. S/Res/955 (I994); 33 ILM I598 (1994) (hereinafter ICTR Statute).

2 H. Olásolo, The Criminal Responsibility of Senior Political and Military Leaders as Principals to International Crimes (Hart Publishing, Oxford, 2009), at 20 (hereinafter Olásolo). See also A. Cassese, International Criminal Law (Oxford University Press, Oxford, 2008), at 33 (hereinafter Cassese). E. van Sliedregt, Individual Criminal Responsibility in International Law (Oxford University Press, Oxford, 2012), at 6I (hereinafter van Sliedregt) and G. Werle, Principles of International Criminal Law (TMC Asser Press, The Hague, 2005).

France et al. v. Goering et al., (1946) 22 IMT 203.

4 Nuremberg Principle VII. 
ad hoc international criminal tribunals in particular has led to ambiguity on its precise parameters. ${ }^{5}$ As noted by Badar, the development of the doctrine of joint criminal enterprise at the ICTY has been nicknamed the "Just Convict Everyone" doctrine because all individuals who participated in the commission of the crime were categorised as perpetrators irrespective of the degree of their participation. ${ }^{6}$ If this is the case is there an on-going requirement in the realm of international criminal justice to develop an alternative mode of responsibility to ensure that international criminal law can be applied to new types of entities? As a counterpart to Badar's belief in the over-expansive nature of the joint criminal enterprise doctrine, one must highlight the risk that the application of an overly restrictive principle of individual criminal responsibility would limit the extent to which members of network-based transnational terrorist groups could be held accountable for terrorist attacks before the ICC. In any event, the ICC has arguably side-stepped this dilemma by developing the doctrine of co-perpetration which specifies that an individual can be held responsible for a crime if he or she made an essential contribution towards it commission. ${ }^{7}$ So would the doctrine of coperpetration provide a more sufficient basis upon which to hold members of transnational terrorist groups accountable, or is the adoption of this mode of responsibility merely a re-labelling of the JCE doctrine developed by the ICTY?

It is not possible within the confines of this article to examine in detail the development and conceptual basis for the principle of individual criminal responsibility in general. However, as I will examine the adoption of the doctrine of co-perpetration by the ICC in the Lubanga and Katanga cases with reference to the organisational structure of the transnational terrorist group, it is necessary to understand the specific contribution of each member in the perpetration of the terrorist attack. Each participating member of the group in the terrorist attack may have played a different role in the planning, organization, co-ordination and execution of the crime. Furthermore, it is important to distinguish between members of transnational terrorist groups which made a contribution towards the commission of the terrorist attack and the members who had no role whatsoever in the perpetration of the crime.

Since the ICC has not yet had to examine the application of the Rome Statute to terrorist groups with a network-based organisational structure, the argument I have advanced over the course of this

\footnotetext{
A. Eser, "Individual Criminal Responsibility" in A. Cassese, P. Gaeta and J Jones, eds., The Rome Statute of the International Criminal Court: A Commentary: Vol. I (Oxford University Press, Oxford, 2002) 767, at 784 (hereinafter Eser).

6 M. Badar, “Just Convict Everyone!' - Joint Perpetration: From Tadić to Stakić and Back Again” (2006) 6 International Criminal Law Review 293 (hereinafter Bader). See also A. Danner and J. Martinez, "Guilty Associations: Joint Criminal Enterprise, Command Responsibility, and the Development of International Criminal Law” (2005) 93 California Law Review 75. For a defence of JCE see A. Cassese, "The Proper Limits of Individual Responsibility under the Doctrine of Joint Criminal Enterprise" [2007] 5 Journal of International Criminal Justice 109. For examples of case-law on the JCE doctrine see: Prosecutor v. Tadić, IT-94-I-A, Appeals Chamber, I5 July 1999 at paras. 185 et seq (hereinafter Tadić); Prosecutor v. Vasiljević, Judgment (IT-98-2I-A), Appeals Chamber, 25 February 2004 at para. I82; Prosecutor v. Krstić (IT-98-33-A), ICTY Appeals Chamber, I9 April 2004 at para. 268 (hereinafter Krstić); Prosecutor v. Laurent Semanza, ICTR-97-20-T, Judgment of 15 May 2003 at paras. 408, and 410-419; Prosecutor v. Taylor, Case No. SCSL-03-0I-T, Trial Chamber II, Judgement (I8 May 20I2) at paras. 6953 and 6971; Prosecutor v. Charles Ghankay Taylor, Judgment of the Appeals Chamber, SCSL-03-oI-A (I0766-III4), A. Ch., 26 September 2013 at para. 670 (hereinafter Charles Taylor). For further academic commentary see van Sliedregt, supra n. 2, at 77; Casesse, supra n. 2, at 324-325 and G. Werle, "Individual Criminal Responsibility in Article 25 ICC Statute" [2007] 5 Journal of International Criminal Justice 953, at 955 (hereinafter Werle).

Decision on the Confirmation of Charges, Pre-Trial Chamber ICC-oI/04-01/06 29 January 2007 (hereinafter Lubanga Confirmation Decision). Prosecutor v. Germain Katanga and Matbieu Ngudjo Chui, Decision on the Confirmation of Charges, Pre-Trial Chamber, ICC-oI/04-0I/07, 30 September 2008 at para. 525 (hereinafter Katanga and Chui Confirmation Decision). C. Roxin, "Crimes as Part of Organized Power Structures" (translated by B. Cooper) [20II] 9 Journal of International Criminal Justice 193 (hereinafter Roxin).
} 
article is that due to the limited development of accountability mechanisms before the ICC the prosecution of transnational terrorist groups will be difficult. On the basis of this understanding, the key question that needs to be asked is: can members of transnational terrorist groups be held accountable under Article 25 of the Rome Statute despite their network-based organisational structure? I will argue that since some transnational terrorist groups have a network-based organisational structure it is difficult to ascertain whether their attacks were committed in pursuance of a joint criminal plan. Therefore, for a member of a transnational terrorist group to be held accountable under Article 25 we need to ascertain whether their conduct satisfies the constituent elements of the doctrine of direct and indirect co-perpetration as developed by the Pre-Trial and Trial Chambers in the Lubanga and Katanga cases. ${ }^{8}$ So while there have been a range of authoritative statements from academics and the judiciary at the ICC on the application of Article 25 to armed opposition groups with clear-cut hierarchical command structures we cannot definitively say that members of transnational terrorist groups can be held accountable under Article 25 in view of their network-based organisational structure. ${ }^{9}$

Nonetheless, I propose that although the doctrine of co-perpetration is an attempt to develop an overall theory of accountability at the ICC the concept of control under the doctrine is onedimensional especially when applied to entities such as transnational terrorist groups which may not have a centralised command in view of their network-based organisational structure. Instead, I advance the argument that a more inclusive approach to joint perpetration which includes both objective and subjective elements would be more appropriate. The relevant factors include the subordinate member's involvement in the planning of the terrorist attacks by the transnational terrorist group and his/her own mens rea. So in network-based transnational terrorist groups, it is hard to determine the member's contribution towards the commission of the terrorist attacks and the propinquity of his contribution to the actual perpetration of the criminal offence. However, before considering this question this article will analyse how the ICC has utilised Roxin's control theory of perpetration in its interpretation of Article 25 of the Rome Statute. I will therefore now analyse how the Pre-Trial and Trial Chambers' decisions in the Lubanga and Katanga cases have applied Article 25 to armed groups with clear cut organisational structures before then examining whether the application of the provision to transnational terrorist group is constrained by their network-based organisational structure.

\section{THE PRINICPLE OF INDIVIDUAL CRIMINAL REPSONSIBILITY} UNDER ARTICLE 25 OF THE ROME STATUTE

Article 25 of the Rome Statute sets out a comprehensive legal framework on criminal responsibility. According to Saland, who chaired the Working Group on General Principles of Criminal Law during the negotiations to establish the ICC, the provision:

[...] posed great difficulties to negotiate in a number of ways. One problem was that experts from different legal systems took strongly held positions, based on their national laws, as to the exact content of the various concepts involved. They seemed to find it hard to

$8 \quad$ Katanga and Chui Confirmation Decision, supra n. 7, at para. 525. Roxin, supra n. 7.

9 J. Ohlin, "Three Conceptual Problems with the Doctrine of Joint Criminal Enterprise" [2007] 5 Journal of International Criminal Justice 69. See also Werle, supra n. 6, at 955. 
understand that another legal system might approach the issue in another way: e.g.; have a different concept, or give the same name to a concept but with a slightly different content. ${ }^{10}$

Although the initial draft of Article 25 originates from the International Law Commission's Draft Code of Crimes against the Peace and Security of Mankind, the official draft of the provision was proposed by "an informal group representing various legal systems." ${ }^{\text {II }}$ Hence, the official draft of Article 25 is inspired by both domestic criminal law and international legal instruments. ${ }^{\mathrm{I} 2}$ The extensive literature on Article 25 indicates that academics interpret the provision on the basis of their own experience and comprehension of criminal liability. Both Ambos and Werle have suggested that Article 25 exemplifies both a differentiated and hierarchical approach to criminal participation, ${ }^{13}$ while Eser argues that "it is difficult to find an unambiguous answer" to the question of what modes of criminal participation it incorporates. ${ }^{14}$

\section{(I) The Judicial Approach to Interpreting Article 25 in the Lubanga and Katanga Cases}

The ICC Pre-Trial Chamber in the Lubanga case has developed an alternative approach based on Roxin's control theory of perpetration. ${ }^{\text {Is }}$ The Chamber analysed the approach of domestic jurisdictions in differentiating between perpetrators and accomplices. ${ }^{16}$ In particular, the Pre-Trial Chamber noted that common law jurisdictions such as the UK have adopted an objective approach to perpetration. ${ }^{17}$ Pursuant to this approach the perpetrator is described as the person who carried out the actus reus of the crime while the individual who provided material support towards its commission is simply defined as an accomplice. ${ }^{\mathrm{I}}$ However, this leads to a contradictory scenario

Io P. Saland, "International Criminal Law Principles" in R. Lee, ed., The International Criminal Court: TheMaking of the Rome Statute: Issues Negotiations and Results (Martinus Nijhoff Publishers, The Hague, 1999) I89, at 198.

II See generally Working Paper Submitted by Canada, Germany, Netherlands, and the United Kingdom, UN Doc. A/AC.249/1997/WG.2/DP.I.

i2 Van Sliedregt, supra n. 2, at 64 and 65.

13 K. Ambos, "Article 25: Individual Criminal Responsibility" in O. Triffterer, ed., Commentary on the Rome Statute of the International Criminal Court (Oxford University Press, Oxford, 2008), at 743 (hereinafter Ambos); Werle, supra n. 6, at 956-7. See also L. Yanev and T. Kooijmans, "Divided Minds in the Lubanga Trial Judgment: A Case against the Joint Control Theory" [2013] I3 International Criminal Law Review 789, at 804.

I4 Eser, supra n. 5 , at 786.

15 C. Roxin, Täterschaft und Tatherrschaft, $8^{\text {th }}$ ed. (Berlin: de Gruyter, 2006). Prosecutor v. Thomas Lubanga Dyilo, Decision on the Confirmation of Charges, Pre-Trial Chamber ICC-oI/04-or/o6, 29 January 2007 (hereinafter Lubanga Confirmation Decision). Prosecutor v. Matbieu Ngudjolo Chui, Jugement Rerndu en Application de l'Article 74 du Statut, Trial Chamber II, ICC-OI/O4-02/I2, I8 December 2012 (hereinafter Chui). Prosecutor v. Omar Hassan Abmad Al-Bashir, Second Arrest Warrant, Pre-Trial Chamber, ICC-02/05-0I/09, I7 July 2010 at para. 4. For further academic commentary see T. Weigend, "Intent, Mistake of Law, and Co-Perpetration in the Lubanga Decision on Confirmation of Charges" [2008] 6 Journal of International Criminal Justice 471, at 478-79 (hereinafter Weigend). See also Katanga and Chui Confirmation Decision, supra n. 7, at paras. 500-518. See also Defence Brief on Matters the Defence Raised during the Confirmation - Legal Observations, ICC-OI/O4-OI/06-758-Conf at para. 33 where the defence argued that it went "beyond the clear terms of coperpetration and indirect perpetration set out in the Statute, and is not supported by either customary international law, or general principles of law derived from legal systems of the world." See also para. 34 of the brief where the defence contends that the concept of joint control over a crime in German criminal law theory was "very much predicated on notions of hierarchy and obedience, and were formulated to address the type of systematic criminality which existed in Germany during world War II (as exemplified in the Eichmann case) and during the communist regime in the GDR.”

${ }_{16}$ Ibid. at paras. $327-332$.

17 Ibid.

I8 Lubanga Confirmation Decision, supra n. 7, at para. 328. For further analysis see G. Fletcher, Retbinking Criminal Law (Oxford University Press, Oxford, 2000), at 654-55 (hereinafter Fletcher). 
whereby the commander who orders his or her subordinates to carry out an attack will be convicted as an accomplice because he does not himself physically carry out the attack. A straightforward examination of the events leading up to the perpetration of the attack suggests that the commander of the state armed force or non-state armed actor should be held more culpable than the subordinate who carries out the crime. As a result, the "common law [has] developed numerous doctrinal techniques to mitigate this shortcoming in its jurisprudence, most notably deemphasising or even collapsing the distinction between principals and accessories." ${ }^{19}$ Hence, UK criminal law provides that accomplices and principals can be held equally culpable and face the same punishment. ${ }^{20}$

The Pre-Trial Chamber also referred to the "subjective approach" to perpetration which has been applied by courts in civil law jurisdictions such as Germany. ${ }^{21}$ This approach emphasises the mens rea of the individual involved in the commission of the crime. Under this approach the commander can be convicted as the principal perpetrator because he exhibits the necessary mens rea for the crime to be committed. ${ }^{22}$ However, this approach has been criticised because the individual with the requisite mens rea may be "casually, temporally, and geographically removed from the physical commission of the crime - a tenuous connection that some [...] feel is emblematic of the [...] causal connection between the defendant and the resulting crime." ${ }_{23}$ As a result, the question arises whether it is reasonable to classify the commander of a transnational terrorist group as a principal perpetrator given that he or she may have been geographically removed from the location where the crime occurred?

Roxin's control theory of perpetration overcame this obstacle by proposing a third approach which amalgamated both the objective and subjective approaches to perpetration. Pursuant to this approach the perpetrator is defined as the person who has control of the act and determines whether the crime will be committed. However, the Pre-Trial Chamber in the Lubanga case went even further than this and described a perpetrator as the individuals who:

[p]hysically carry out the objective elements of the offence, but also include those who, in spite of being removed from the scene of the crime, control or mastermind its commission because they decide whether and how the offence will be committed. ${ }^{24}$

Therefore, a "person who acts through another may be [held] individually criminally responsible, regardless of whether the executor (the direct perpetrator) is responsible [for the crime]."25 If two persons have joint control over the commission of the crime they are classified as co-perpetrators. In domestic criminal cases involving crimes such as murder, the control theory will produce the same result as the subjective and objective approaches combined. This is because the majority of murder cases are perpetrated by just one person who carries out the actus reus, possesses the requisite mens rea and ultimately exercises control over the criminal offence. So if the accused carries out the

\footnotetext{
19 Ibid.

${ }_{20}$ Davies v. DPP [1954] AC 378.

${ }_{21} \quad$ Lubanga Confirmation Decision, supra n. 7 , at para. 328 .

22 Ibid. at para. 329.

23 J. Ohlin, "Co-Perpetration: German Dogmatik or German Invasion?" in C. Stahn, ed., The Law and Practice of the International Criminal Court: A Critical Account of Challenges and Acbievements (Oxford University Press, Oxford, forthcoming), at 57 [Ohlin Dogmatik]. See also Cassese, supra n. 2, at 191. For further analysis on this point see K. Ambos, Treatise on International Criminal Law (Oxford University Press, Oxford, 2013), at $201 \mathrm{I}-\mathrm{I} 2$.

24 Lubanga Confirmation Decision, supra n. 7, at para. 330.

${ }^{25}$ Katanga and Chui Confirmation Decision, supra n. 7, at para. 496. See also C. Roxin, "Straftaten im Rahmen organisatorischer Machtapparate," Goltdammer's Archiv für Strafrecht (1963) at 193-207.
} 
murder, intends the killing to occur and also displays control over whether or not the killing does in fact occur he or she will be classified as the perpetrator.

Nevertheless, international crimes are very different to domestic crimes for a number of reasons. Firstly, international crimes are generally "perpetrated by a plurality of persons, making coperpetration [...] crucial to prosecutorial strategy." ${ }^{\prime 6}$ Secondly, and most importantly, the individual in control of the crime may not necessarily participate in the actual international crime. Instead, the individual in control of the crime is usually high up in the hierarchical chain of command whilst the subordinates carry out the actus reus. ${ }^{27}$ The Eichmann Trial in Israel inspired Roxin to expand his theory to include indirect perpetration and organization perpetration. ${ }^{28}$ With regard to indirect perpetration, Roxin contended that the accused should be held accountable as a principal perpetrator because despite not performing the actus reus of the crime he or she is still an indirect perpetrator who relies on his or her subordinates to carry out the physical act. ${ }^{29}$ The Eichmann Trial provided Roxin with the opportunity to expand his control theory to include perpetrators who "indirectly perpetrate the crime by using an organization as an instrument to perform the international crime." ${ }^{30}$ Roxin described this as the 'Organisationsherrschaft' which entails the use of an organization as a means to perpetrate criminal acts..$^{31}$ The individual at the very top of the chain of command is described as the 'Hintermann' who controls the perpetration of the crime by devising the criminal plan to be carried by the subordinates. . $^{2}$

Although Roxin's theory was enthusiastically accepted by German legal theorists it was not applied by German courts until three decades later when the Border Guard cases were adjudicated. ${ }^{33}$ Following

${ }_{26}$ Ibid. See also J.D. Ohlin, "Joint Intentions to Commit International Crimes" [20II] in Chicago Journal of International Law 693 [Ohlin Joint Intentions].

${ }_{27}$ Ohlin; Dogmatik, supra n. 23, at 56. See also K. Ambos, "Command Responsibility and Organisationsherrschaft: Ways of Attributing International Crimes to the 'Most Responsible”, in A. Nollkaemper and H. van der Wilt, eds., System Criminality in International Law (Cambridge University Press, Cambridge, 2009) I27, at I52.

28 Attorney General of the Government of Israel v. Eichmann (District of Jerusalem) (196I), 36 International Law Reports 5, as reprinted in E. Lauterpacht, ed., The Eichmann Judgments (Butterworths, London, 1968), \$16, at 29-30. For further academic commentary on the trial see: H. Arendt, Eichmann in Jerusalem: A Report on the Banality of Evil (Penguin Books, London, 2006); J. N. Shklar, Legalism (Harvard University Press, Cambridge, 1964), at 154-155. M. J. Osiel, Mass Atrocity, Ordinary Evil and Hannab Arendt (Yale University Press, Yale, 200I), at 6I-62; W. Schabas, Genocide in International Law (Cambridge University Press, Cambridge, 2000), at 286 (hereinafter Schabas). See also A. Cassese, International Criminal Law (Oxford University Press, Oxford, 2013), at II4; G. Bass, "The Adolf Eichmann Case: Universal and National Jurisdiction" in S. Macedo, ed., Universal Jurisdiction: National Courts and the Prosecution of Serious Crimes Under International Law (University of Pennsylvania Press, Pennslyvania, 2004), 77-90; L. Bilsky, "The Eichmann Trial and the Legacy of Jurisdiction" in S. Benhabib, ed., Politics in Dark Times: Encounters with Hannab Arendt (Cambridge University Press, Cambridge, 2010), at 198; I. Mann, "The Dual Foundation of Universal Jurisdiction: Towards a Jurisprudence for the Çourt of Critique" [2010] I(4) Transnational Legal Theory 485; W. Schabas, "The Contribution of the Eichmann Trial to International Law" [2013] 26 Leiden Journal of International Law 667; For criticism of victims' testimonies in the Eichmann trial see S. Landsman, "The Eichmann Case and the Invention of the Witness-Driven Atrocity Trial” [20I2] 5I Columbia Journal of Transnational Law 69. For a more general criticism of the reliance on testimonies of survivors by international tribunals see, N. Combs, Fact-Finding Without Facts (Cambridge University Press, Cambridge, 20Io). See generally Roxin, supra n. 7 .

29 Fletcher, supra n. 18, at 639.

30 Ohlin: Dogmatik, supra n. 23, at 59. See also Roxin, supra n. 7, at 193.

31 Roxin, supra n. 7, at 193.

32 Ibid.

33 Bundesgerichtshof (Federal Court of Appeals), Judgment of 26 July 1994, in 40 Entscheidungen des Bundesgerichtshofes in Strafsachen, (1995) 218-240, at 236. 
the unification of Germany, the state authorities prosecuted East German civilians as they tried to escape across the Berlin Wall to West Germany. The killings generated fear amongst East Germans that inhibited them from conducting escape attempts because of the fatal consequences if they failed. It is not remarkable that the German court was reluctant to classify the officials who directed the policy of shoot-to-kill as accomplices and instead tried and convicted them as principal perpetrators. The cases provided German courts with the opportunity to apply Roxin's control theory of perpetration and also moved the theory from a hypothetical concept to doctrinal actuality. ${ }^{34}$

The Pre-Trial Chamber in Prosecutor v. Lubanga and the Trial Chamber II in Prosecutor v. Katanga utilised Roxin's theory as a guide to interpreting Article 25(3)(a) of the Rome Statute. ${ }^{35}$ Circumventing the controversial jurisprudence of the ICTY on JCE, the Pre-Trial Chamber in the Lubanga case concluded that Article 25(3)(a) codifies Roxin's control theory of perpetration. ${ }^{36}$ However, Article 25(3)(a) does not refer to the concept of control whatsoever and merely provides that an individual will be held responsible if he or she "[c]ommits [...] a crime, whether as an individual, jointly with another or through another person [...] ${ }^{\prime 37}$ To add further to the confusion, the Trial Chamber in the Katanga case remarked that this was not the only possible interpretation of Article 25 in general remarking that "elle estime qu'il n'y a pas lieu de faire cette théorie un élément constitutive incontournable de la commission par l'intermédiaire." ${ }^{8}$ Indeed, Article 25(3)(d) provides that individuals will be held responsible for their contribution to collective crimes. As a result the scope of application of Article 25(3)(a) and Article 25(3)(d) to transnational terrorist groups is both ambiguous and broad ${ }^{39}$

\section{THE CRITERIA FOR DETERMINING THE ACCOUNTABILITY OF MEMBERS OF TRANSNATIONAL} TERRORIST GROUPS UNDER ARTICLE 25

Article 25(3)(a) of the Rome Statute defines the perpetrator as the individual who commits a crime "whether as an individual, jointly with another or through another person, regardless of whether that other person is criminally responsible." ${ }^{\circ}$ The Pre-Trial Chamber in the Lubanga case noted that the

34 Ohlin; Dogmatik, supra n. 23, at 6I. See also M. Bohlander, Principles of German Criminal Law (Hart Publishing, Oxford, 2009) at 158. Streletz, Kessler and Krenz v. Germany (Applications No. 34044/96, 35532/97 and 4880I/98) 22 March $200 \mathrm{I}$ (ECHR, Reports of Judgments and Decisions 200I -II), text available at: http://hudoc.echr.coe.int/sites/eng/pages/search.aspx?i=o0I-59353\#\{"itemid":["ooI-59353"]\}, accessed on 5 December 20I4. For a useful synopsis on the human rights issues arising in these cases see R. Geiger, "The German Border Guard Cases and International Human Rights" [1998] 9 European Journal of International Law 540.

35 Lubanga Confirmation Decision, supra n. 7, at para. 324. See also: Katanga Trial Judgment, supra n. 7, at para. I400I4I 2 .

36 Lubanga Confirmation Decision, supra n. 7, at para. 348. However, interestingly the Pre-Trial Chamber did conclude at para. 335 that Article 25(3)(d) "is closely akin to the concept of joint criminal enterprise or the common purpose doctrine adopted by the jurisprudence of the ICTY.” For further reference see Lubanga Confirmation Decision, supra n. 7, at para. 335 .

37 Article 25(3)(a) of the Rome Statute of the International Criminal Court.

38 Katanga Trial Judgment, supra n. 7, at para. I400-I4I2.

39 Many academics have attempted to determine the scope of application of both provisions. For example see: J.D. Ohlin, "Joint Criminal Confusion" [2009] I2 New Criminal Law Review 406 (hereinafter Ohlin) and G. Werle, "Individual Criminal Responsibility in Article 25 of the ICC Statute" [2007] 5 Journal of International Criminal Justice 953. For further reference see the Concurring Opinion of Judge Christine van den Wyngaert, Prosecutor v. Matbieu Ngudjolo Chui, Jugement rendu en application de l'Article $74 \mathrm{du}$ Statut, Trial Chamber II, Case No. ICC-OI/04-02/I2 (I8 Dec. 20I2) at paras. 22-30 (hereinafter Judge Van den Wyngaert Opinion).

40 Article 25(3)(a) of the Rome Statute of the International Criminal Court. 
concept of co-perpetration was premised on "joint control over [...] [a] crime by reason of the essential nature of the various contributions to the commission of the crime." ${ }^{41}$ The Chamber further held that in cases involving joint perpetration the perpetrators of the crime do not control the commission of the criminal act themselves since the defining characteristic of co-perpetration is "the division of essential tasks for the purpose of committing a crime between two or more persons acting in a concerted manner." ${ }^{42}$ Since the perpetration of the crime depends on the successful completion of each participant's contribution "they all share control because each of them could frustrate the commission of the crime by not carrying out his or her task." ${ }^{43}$

\section{(2) An Agreement or Common Plan}

There must be evidence of an agreement or common plan between the members of the transnational terrorist group to carry out the attack. Indeed, the Pre-Trial Chamber in the Lubanga case noted there must be evidence of an "agreement or common plan between two or more persons." ${ }_{4}$ This agreement or common plan can be implied but must contain an element of criminality, even though it does not need to be aimed explicitly at the perpetration of a crime..$^{45}$ If a member of a transnational terrorist group participates in the commission of a criminal offence without co-ordinating with his/her coperpetrators that act does not fall within the meaning of Article 25(3)(a) of the Rome Statute. ${ }^{46}$ At the same time the Chamber recognised that:

when the objective elements of an offence are carried out by a plurality of persons acting within the framework of a common plan, only those to whom essential tasks have been assigned - and who, consequently, have the power to frustrate the commission of the crime by not performing their tasks - can be said to have joint control over the crime. ${ }^{47}$

4I Lubanga Confirmation Decision, supra n. 7, at para. 34I. See also Ambos, supra n. I3, at 479. For further commentary on the Lubanga case see for example R. Graf, "The International Criminal Court and Child Soldiers: An Appraisal of the Lubanga Judgment" [2012] Io Journal of International Criminal Justice 945; M. Kurth, "The Lubanga Case of the International Criminal Court: A Critical Analysis of the Trial Chamber's Findings on Issues of Active Use, Age and Gravity" (2013) 5 Goettingen Journal of International Law 43I; T. Lieflander, "The Lubanga Judgement at the ICC” [2012] I Cambridge Journal of International and Comparative Law I9I.

$42 \quad$ Ibid. at para. 342.

43 Ibid. See also Prosecutor v. Stakić, IT-97-24-A (22 March 2006) at para. 440 (hereinafter Stakić).

44 Lubanga Confirmation Decision, supra n. 7, at para. 343. See also Stakić, supra n. 43, at paras. $470-477$ where the ICTY Trial Chamber sub-divided the first criterion of co-perpetration into two criteria: (i) an agreement or silent consent and (ii) a common plan. For further analysis of the Lubanga case see R. Brownman, "Lubanga, the DRC and the African Court: Lessons Learnt from the First International Criminal Court Case" [2007] 7 African Human Rights Law Journal 4I2.

45 Lubanga Confirmation Decision, supra n. 7, at paras. 343-45; Prosecutor v. Germain Katanga and Matbieu Ngudjolo Chui, ICC-or/04-or/07, Decision on the Confirmation of Charges, 30 September 2008 at paras. 522-23 [hereinafter Katanga and Chui]; Prosecutor v. Francis Kirimi Muthaura, Uburu Muigai Kenyatta and Mobammed Hussein Ali, ICC-oI/o9-02/II, Decision on the Confirmation of Charges, 23 January 2012 at paras. 399-400 [hereinafter Muthaura, Kenyatta and Ali]; Prosecutor v. Abdallab Banda Abakaer Nourain and Saleb Mobammed Jerbo Jamus, ICC-02/05-03/09, Decision on the Confirmation of Charges, 7 March $201 \mathrm{I}$ at paras. I29-I35 [hereinafter Banda and Jerbo]; Prosecutor v. William Samoei Ruto, Henry Kiprono Kosgey and Joshua Arap, ICC-oI/o9-oI/II, Decision on the Confirmation of Charges, 23 January 2012 at paras. 30I-304 hereinafter Ruto et al.]; Prosecutor v. Babar Idriss Abu Garda, ICC-02/05-02/09, Decision on the Confirmation of Charges, 8 February 2010 at paras. 160 and 163-232 [hereinafter Abu Garda].

${ }_{46}$ Lubanga Confirmation Decision, supra n. 7, at para. 343.

47 Ibid. at para. 347 . 
So the fundamental criterion of joint perpetration of a terrorist attacks is the power to aggravate the commission of an offence "by not performing their [assigned] tasks." ${ }^{8}$ In view of the fact that this criterion is expressed in negative terms it would seem that there exists "no particular affirmative act that a person must perform in order to become a joint perpetrator." ${ }^{49}$

The Trial Chamber does not require that the common plan must be inherently criminal providing that it contains some element of criminality. The execution of the plan must therefore involve "a sufficient risk that if events follow the ordinary course, a crime will be committed." ${ }^{\circ}$ The Chamber also dithers between an objective and subjective approach to co-perpetration. At the outset, the Trial Chamber stressed that pursuant to Article 30 of the Rome Statute co-perpetrators must be subjectively cognisant of the risk that the execution of the common plan could lead to the perpetration of a crime..$^{\mathrm{I}}$ In particular, the Trial Chamber emphasised that "the mental requirement that the common plan included the commission of a crime will be satisfied if the co-perpetrators knew that, in the ordinary course of events, implementing the plan will lead to that result." 52 Although, the Trial Chamber adopted the correct approach it has been tempered by subsequent formulations which have been supplanted by the requirement that the execution of the plan "will result in the commission of the relevant crime in the ordinary course of events." 53

Judge Fulford, in his dissenting opinion in the Lubanga case, proposed an alternative approach which more accurately represents the language of Article 25 and simply requires a common plan between a number of individuals who work together to produce a particular result. ${ }^{54}$ Judge Fulford rationalised his approach by noting that:

$[t]$ his self-evidently necessitates a sufficient meeting of minds, by way of an agreement, common plan or joint understanding. In practice, this will not always be explicit or the result of long-term planning, and the existence of the joint venture may need to be inferred from the conduct of co-perpetrators.5

This approach would side-step the concept of control which is at the very heart of Roxin's theory and the doctrine formulated by the Pre-Trial Chamber in the Lubanga case. The co-perpetration of an

48 Katanga and Chui Confirmation Decision, supra n. 7, at para. 525.

49 Ohlin et al., "Assessing Control Theory" [2013] 26 (3) Leiden Journal of International Law 344, at 346 (hereinafter Ohlin et al).

so Prosecutor v. Thomas Lubanga Dyilo, ICC-oI/04-0I/06 Judgement I4 March 2012 at para. $984-987$ (hereinafter Lubanga Judgment). See also K. Ambos, "The First Judgment of the International Criminal Court: (Prosecutor v. Lubanga): A Comprehensive Analysis of Legal Issues” [2012] I2 International Criminal Law Review II5 and T. Mariniello, Prosecutor v. Thomas Lubanga Dyilo: The First Judgment of the International Criminal Court's Trial Chamber" [2012] International Criminal Law Review 137 .

${ }_{51}$ Ibid. at para. 986. See also: J. Rodriguez-Villasante y Prieto, "Los Principles Generales del Derecho Penal en el Estatuto de la Roma de la Corte Penal Internacional” (2000) 75 Revista Espanola de Derecho Militar 4I7; D. Piragoff, "Article 30: Mental Element" in O. Triffterer, ed., Commentary on the Rome Statute of the International Criminal Court (Nomos, Baden-Baden, 1999) 534; E. Van Sliedregt, The Criminal Responsibility of Individuals for Violations of International Humanitarian Law (TMC Asser Press, The Hague, 2003) 87.

$52 \quad$ Ibid.

53 Lubanga Judgement, supra n. 50, at para. Ior8.

54 Separate Opinion of Judge Fulford, ICC-OI/04-0I/06-2842 (I4 March 2012) at para. I5 (hereinafter Dissenting Opinion of Judge Fulford).

55 Ibid. at para. 15 
international crime would simply require a mutual intention among the co-perpetrators. ${ }^{56}$ Arguably, Judge Fulford's explanation of co-perpetration accurately describes the network-based structure and collective criminality of transnational terrorist groups. ${ }^{57}$ Indeed, evidence that the accused acquiesced to a criminal plan to carry out terrorist attacks could be inferred from his membership of the transnational terrorist group alone. Since the member of a transnational terrorist group either agrees or reaches a mutual understanding with others to commit a crime and wants the result achieved by the group then the particular action should be attributed to that member for being a participant in the collective action.

\section{(3) The Contribution towards the Commission of the Crime}

Article $25(3)(d)$ of the Rome Statute does not make any reference to whether the accused must be a member of the group committing the criminal offence. The provision simply states that an accused will be held accountable if he/she "contributes to the commission or attempted commission of such crime by a group of persons acting with a common purpose." 88 The provision further provides that the contribution must be made "with the aim of furthering the criminal activity or criminal purpose of the group" or "be made in the knowledge of the intention of the group to commit the crime." 59 In view of the fact that there is no reference in Article 25 to whether the accused who is alleged to have made a "contribution" to the perpetration of a criminal offence by a group must be a member of this group one should be cautious before reading such a requirement into the provision.

Evidence that Article 25(3)(d) does not require that the accused be a member of a transnational terrorist group can be inferred from the contention that the wording of the provision was scrounged from Article 2(3) of the International Convention on the Suppression of Terrorist Bombing, 1997 which was open for ratification around the same time the Rome Statute was drafted. ${ }^{60}$ Article $2(3)$ of the Convention provides that an individual can be held responsible if they:

[i]n any other way contributes to the commission of one of more offences as set forth in paragraph I or 2 by a group of persons acting with a common purpose; such contribution shall be intentional and either be made with the aim of furthering the general criminal activity or purpose of the group or be made in the knowledge of the intention of the group to commit the offence or offences concerned. ${ }^{61}$

However, this interpretation of the term "contributes" in Article 25(3) (d) of the Rome Statue is not persuasive because Article 2(3)(b) of the International Convention on the Suppression of Terrorist Bombing 1997 provides that an individual is responsible if he or she "[o]rganises or directs others to

6 Ohlin Joint Intentions, supra n. 26, at 742.

57 Dissenting Opinion of Judge Fulford, supra n. 54.

58 Article 25(3)(d) of the Rome Statute of the International Criminal Court. See also Lubanga Judgment, supra n. 50, at paras. 346-48; Katanga and Ngudjolo, supra n. 45, at paras. 524-26; Muthaura, Kenyatta and Ali, supra n. 45, at paras. 40I-406; Banda and Jerbo, supra n. 45, at paras. 136-149; Ruto, Kosgey and Sang, supra n. 45, at paras. 305-312; Prosecutor v. Abu Garda, supra n. 45 , at paras. $160,180-232$.

59 Ibid.

60 International Convention for the Suppression of Terrorist Bombings, G.A. Res. 164 Art. 2(3)(c) at 389, U.N. GAOR, 52nd Sess., Supp. No. 49, U.N. Doc. A/52/49 (Jan. 8, 1998). See D. Cassel, "Corporate Aiding and Abetting of Human Rights Violations: Confusion in the Courts” [2008] 6 Nw. U. J. Int'l Hum. Rts. 304, at 313.

${ }_{61}$ Ibid. The judgment of the ICTY Appeals Chamber noted in the Tadić case, supra n. 6 where it was stated at para. 22I that that the drafting history of the Terrorism Convention "does not shed any light on the reasons behind the adoption of this text." For further reference see Tadic, supra n. 6, at para. 22I. 
commit an offence as set forth in paragraph I or 2." ${ }^{62}$ This provision in turn clarifies the meaning of Article 2(3)(c) of the Convention which states that an individual will be held liable if he or she "[i]n any other way contributes to the commission of one or more offences as set forth in paragraph I or 2 by a group of persons acting with a common purpose." ${ }^{63}$ It is clear from the wording of this convention that the contribution comes from outside the criminal group. However, there is no equivalent provision in the Rome Statute. The "outside contributor" interpretation of Article 25(3)(d) of the Rome Statute can thus be challenged on the grounds that Article 25(3)(b) already prohibits an act of facilitating, aiding and abetting, or assisting in the commission of a crime.

\section{(a) The Essentiality of the Contribution}

The individual's contribution must also be essential to ensure the successful commission of the terrorist attack. The criterion:

reflects the value judgment that those who provide vital contributions to the commission of a crime are, in general, more blameworthy than those who remain at the margins of the criminal enterprise and provide only support that the main actors could have done without. $^{64}$

Nevertheless, the control theory of perpetration advocated by the Pre-Trial Chamber is problematic when applied to transnational terrorist groups in view of their organisational structure because the criteria for determining whether an act was "essential" in order for the commission of the criminal offence to be successful are ambiguous. ${ }^{65}$

Indeed, the essentiality of the contribution towards the execution of the common criminal plan can be determined from either a subjective or objective approach. ${ }^{66}$ However, this determination would be more straightforward if one evaluates the individual's contribution from the planning stages of the offence. If this approach was adopted it would be easier to determine whether the individual's contribution was valuable but not critical for the successful perpetration of the offence. Indeed, the Trial Chamber in the Lubanga case appears to have analysed the accused's contribution towards the commission of the crime from a subjective perspective. In particular, the Trial Chamber noted at paragraph Iooo of its judgment that:

[t]he determination as to whether the particular contribution of the accused results in liability as a co-perpetrator is to be based on an analysis of the common plan and the role

${ }_{62}$ Article 2(3)(b) of the International Convention on the Suppression of Terrorist Bombing 1997.

63 Ibid.

${ }^{64}$ Ibid. See also N. Jain, "The Control Theory of Perpetration in International Criminal Law" [20II] I2(I) Chicago Journal of International Law 184.

${ }_{65}$ See generally L. Yanov and T. Kooijmans, "Divided Minds in the Lubanga Trial Judgment: A Case against the Joint Control Theory" [2013] I3(4) International Criminal Law Review 789.

66 Ibid. 
that was assigned to, or was assumed by the co-perpetrator, according to the division of tasks. ${ }^{67}$

The prosecution proposed that co-perpetration requires a subjective approach where the "[a]ccused must have been assigned a role that was central to the implementation of the common plan." ${ }^{68}$ At the same time, the prosecution adapted this proposed requirement by arguing that "as long as the accused was assigned a central role in the implementation of the plan, it will suffice if in retrospect it appears his or her contribution was substantial, rather than essential." ${ }^{69}$ The ICC Trial Chamber did not embrace this approach and as a result the question remains whether the criteria of joint perpetration should be evaluated from an objective or subjective approach. ${ }^{70}$

If the subjective approach is to be preferred the judge must accede as binding any error committed by the perpetrators during the commission of the terrorist attack. So if the high ranking members of a transnational terrorist group decide that the bombing of a supermarket will only succeed if one of the subordinate members of the group provides a vehicle to transport the bomb to the location of the supermarket this expectation under the subjective approach infers that the member of the group who provided the vehicle to carry out the terrorist attack is a joint perpetrator. In addition, the subordinate member of the transnational terrorist group would still be classified as a joint perpetrator even if the vehicle was not ultimately used to transport the bomb to the location and instead the bombing was carried out by a different member of the group who transported the bomb to the supermarket on foot in a rucksack. On the other hand, the objective approach, which would determine whether the member's provision of the vehicle was 'essential' for the successful perpetration of the bombing, would arguably side-step this difficulty. If the transnational terrorist group actually uses the vehicle provided by the member to transport the bomb to the supermarket it is uncertain what the result would have been if the member had not provided the vehicle. Perhaps the commanders of the transnational terrorist group would have decided not to carry out the bombing or perhaps they would have found an alternative means of transporting the bomb to the supermarket?

Judge Fulford, in his dissenting opinion, was of the view that the definition of an "essential" contribution to the criminal plan was too narrow ${ }^{71}$ and proposed a more straightforward test for joint perpetration:

"[n]othing in the Statute required that the contribution must involve direct, physical participation at the execution stage of the crime, and instead, an absent perpetrator may be involved. Either way, the use of the word 'commits' simply requires an operative link between the individual's contribution and the commission of the crime."72

The application of this alternative test would allow a court to side-step a hypothetical examination of how the transnational terrorist group was able to commit the terrorist attack without the

${ }^{67}$ Lubanga Judgment, supra n. 50, at para. I000. See also Weigend, supra n. 15; R. Clark, "Drafting a General Part to a Penal Code: Some Thoughts Inspired by the Negotiations on the Rome Statute of the International Criminal Court and by the Court's First Substantive Law Discussion in the Lubanga Dyilo Confirmation Proceedings" [2008] Criminal Law Forum 540, at 545; Schabas, supra n. 28, at 429.

68 Lubanga Judgment, supra n. 50, at para. 990.

69 Ibid. at para. 99I.

70 Ohlin et al., supra n. 49, at footnote 30.

7 Dissenting Opinion of Judge Fulford, supra n. 54, at para. 15.

72 Ibid. 
subordinate's involvement. ${ }^{73}$ Judge Fulford concluded that "the plain text of Article 25(3) does not require proof that the crime would have been committed absent the accused's involvement [...] . ${ }^{74} \mathrm{He}$ compares this "operative link" with causation ${ }^{75}$ and suggests that in order to establish co-perpetration there must be "a causal link between the individual's contribution and the crime." ${ }^{6}$ This in turn raises questions about Judge Fulford's understanding of the phrase "causal link." 77 With regard to an act that is pivotal for the commission of a criminal offence, it is unclear whether this act establishes a "causal link" between it and the commission of the criminal offence. This is particularly problematic with regard to the prosecution of transnational terrorist groups because it is often unclear what specific role the accused played in the commission of the terrorist attack because of the group's network-based organisational structure. The lack of communication between the cells of the group means that a subordinate member may carry out a particular task without realising that he or she has made a contribution towards the perpetration of a terrorist attack. Unfortunately, Judge Fulford did not consider this question in his dissenting opinion and as a result, the parameters of his proposed test are ambiguous and do not specify the precise criteria from which to make a distinction between perpetration and accessorial liability. ${ }^{78}$

At the same time, the Pre-Trial Chamber defines the concept of a perpetrator too broadly. The manner in which the Pre-Trial Chamber applied the essentiality requirement to the facts of the case clearly shows how widely it can be applied. The ICC Trial Chamber agreed with the prosecution's submission "that '[i]t is not necessary that the accused physically perpetrated any of the elements of the crimes or that he was present at the crime scene."79 The Trial Chamber held that individuals who jointly carry out a crime "include, inter alia, those who assist in formulating the relevant strategy or plan, become involved in directing or controlling other participants or determine the roles of those involved in the offence." ${ }^{80}$ As a result, the prosecution does not need to prove a "direct or physical link between the accused's contribution and the commission of the crimes." ${ }^{81}$ However, if a distinction is made between the members of the transnational terrorist group who played a central role in the commission of the offence (perpetrators) and the members who merely played a supporting role (accessories) the simplistic criterion of the essentiality of the contribution towards the commission of the offence is inadequate because it describes only one aspect of the particular offence.

Judge Van den Wyngaert, in her Concurring Opinion in the Chui case, agreed with the view of Judge Fulford that the control theory advocated by the Pre-Trial Chamber in the Lubanga case is inconsistent with Article 25(3)(a) of the Rome Statute. ${ }^{82}$ Instead, she proposed that:

[f]or joint perpetration, there must, in my view, be a direct contribution to the realisation of the material elements of the crime. This follows from the very concept of joint perpetration.

\footnotetext{
3 Ibid. at para. I7.

74 Ibid. at para. 15 .

75 Ibid. at para. 16.

${ }^{76}$ Ibid.

7 Ohlin et al. are of the same view. See further Ohlin et al., supra n. 49, at 154.

${ }_{78}$ Ibid. There is on-going controversy as to whether there exists a hierarchical grading of liability in Article 25. For further commentary on this point see: G. Werle, "Individual Criminal Responsibility in Article 25 ICC Statute" [2007] 5 Journal of International Criminal Justice 953.

79 Lubanga Judgment, supra n. 50, at paras. 1003 and 1004.

8o Ibid. at para. I004.

8r Ibid. at para. 1004 (Emphasis Omitted).

82 Judge Christine Van den Wyngaert Opinion, supra n. 39, at paras 41, 42 amd 43. Judge Van de Wyngaert was also of the view that there is no hierarchical ranking of liability in Article 25(3).
} 
Under Article 25(3)(a), only persons who have committed a crime together can be held responsible. The essence of committing a crime is bringing about its material elements. ${ }^{8}$

Similarly to Judge Fulford, she rejected the "essentiality" criterion stating that it obliges the judiciary "to engage in artificial, speculative exercises about whether a crime would still have been committed if one of the accused had not made exactly the same contribution." ${ }^{84}$ She also disagreed with Judge Fulford's approach that any individual who provides some causal element towards the commission of the offence will be deemed a perpetrator. ${ }^{85}$ Instead she proposed that the concept of co-perpetration should only be applied to those individuals who directly commit the material elements of the criminal offence. ${ }^{86}$ Under this approach a member of a transnational terrorist group could be classified as a direct perpetrator of a terrorist attack if he or she plans or organises the commission of the criminal offence. This is because planning, according to Judge Van den Wyngaert, is "an intrinsic part of the actual execution of the crime." ${ }^{87}$ In Prosecutor v. Germain Katanga Judge Van den Wyngaert reiterated her position in her dissenting opinion. ${ }^{88}$

Judge Van den Wyngaert's foremost argument in favour of the "directness" criterion is that it affords equal treatment to both individual perpetrators and joint perpetrators. ${ }^{89}$ Both the individual perpetrator and the joint perpetrators can be held accountable if he or she "brings about" the material elements of the crime. $9^{\circ}$ However, the application of the "directness" criterion to transnational terrorist groups is problematic because the perpetration of a terrorist attack is quite different to the perpetration of the same attack by an individual acting alone. This is because the task of planning and carrying out the act is shared among the members of the group. The court would have to infer the "direct" elements of the offence from the manner in which the terrorist attack occurred. ${ }^{\text {II }}$ Indeed, these members "join [...] [together] for the very purpose of relieving each participant of the necessity to 'bring about' by himself the result of the criminal plan." ${ }^{92}$ If the trial judges must ascertain what particular action is "direct" then perhaps, as Judge Fulford suggested, the question whether the accused member of the transnational terrorist group is in fact a perpetrator of the terrorist attack should be left to the court to decide. At the same time, if it was essential for each member of the transnational terrorist group "to individually fulfil each element of the offence definition, the concept of joint perpetration would be superfluous - every participant could be convicted as an individual perpetrator." 93 The comparison which Judge Van den Wyngaert makes between individual perpetration and joint perpetration sidesteps the very essence of the concept of joint perpetration which is the division of the tasks of planning and carrying out the criminal offence among the participants in the crime.

\footnotetext{
Ibid. at para. 44 .

Ibid. at para. 42.

Ibid. See also para. 43 .

Ibid. at para. 44.

Ibid. at para. 47.

89 Judge Van den Wyngaert Opinion, supra n. 39, at para. 46.

9 Ibid. at para. 45 .

9 I Ibid. at para. 46.

92 Ohlin et al., supra n. 49, at 265.

93 Ibid.
}

Minority Opinion of Judge Christine Van den Wyngaert to Prosecutor v. Germain Katanga, Jugement rendu en application de l'Article $74 \mathrm{du}$ Statut, ICC-OI/04-OI/07-3436, T.Ch.II, 7 March 7 20I4, paras. 277-8I (hereinafter Katanga Trial Judgment). 
An alternative approach would be to infer these criteria from the mens rea of the crime where the prosecution in order to hold members of transnational terrorist groups accountable would have to produce evidence that there was a joint plan devised by members of the group to perpetrate international crimes. However, evidence that plans were drawn up by the members of the group in advance of the terrorist attack may be difficult for the prosecution to prove in light of the clandestine manner in which some transnational terrorist groups operate.

Furthermore, inferring the criteria for determining joint perpetration from the mens rea of the crime would be problematic for two other reasons. First, it is uncertain whether a comprehensible understanding of the mens rea requirement laid down in Article 25(3)(d) in relation to group complicity is conceivable. The wording of the entire provision was not fully conjectured by the drafters of the Rome Statute and was the result of parleyed drafting and negotiations. Article 25(3)(d) on group complicity "includes complex standards of knowledge or purpose for group complicity, allowing for liability for contributions that are intentional and are made with knowledge of the group's criminality." 94 There is no mention whatsoever of what standard of knowledge must be established by the prosecution in order to hold an individual accountable under Article 25(3)(b) of the Rome Statute. However, the issue is not whether a different standard of knowledge must be proved in order to satisfy the requirements of Article 25(3)(b) but the fact that the provision makes no reference to the necessary standards of knowledge whatsoever. This scenario leads to considerable confusion in determining whether a member of a transnational terrorist group should be classified as a joint perpetrator or an individual perpetrator because there is no definitive stipulation of what standards of knowledge should be applied.

Second, Article $25(3)(d)$ of the Rome Statute specifically provides that the contribution to the common criminal endeavour must be intentional. An attack by a transnational terrorist group is the result of a common plan where the instigating members of the group work with the perpetrating members during the initial stages of the common plan to intentionally carry out a terrorist attack. Nevertheless, the term "intentional" in Article 25(3)(d) can be interpreted both broadly and narrowly. If the narrow interpretation of the term is to be preferred this simply denotes that "the bare action performed by the complicitous defendant was the product of an intentional decision" and not an accident. ${ }^{55}$ The problem with this construal of Article 25(3)(d) is that Article 30 of the Rome Statute states that "[u]nless otherwise provided" the necessary mental element of the Statute is both "intent and knowledge." ${ }^{96}$ So a provision of the Rome Statute must only express this alternative mental element where it is different to the default rule laid down in Article $30.9^{7}$

Nevertheless, Article $25(3)$ (d) contains the term "intentional." It is unclear why it was necessary to include this particular word because Article 30 specifically states that Article 25(3)(d) should only specify the required mens rea standard if it wishes to diverge form the default rule. ${ }^{98}$ The only explanation is that the drafters utilised the term "intentional" to distinguish the mens rea standard in Article 25(3)(d) from the mens rea standard laid down in Article 30. This creates further confusion because the provision should have only specified the required mens rea standard if it was different to the mens rea standard laid down in Article 30. Since Article 30 expressly states that "unless otherwise stated" the required mens rea standard is both "intent and knowledge" it could be in conflict with

94 Ohlin, supra n. 9, at 417 .

95 Ibid.

96 Article 30 of the Rome Statute of the International Criminal Court.

97 Ohlin, supra n. 30, at 417.

98 Article 30 of the Rome Statute of the International Criminal Court.

99 Ibid. 
Article 25(3)(d). In particular, the word "intentional" in Article 25(3)(d) refers to the nature of the contribution by which the accused "intends to help the principals, as opposed to a situation where the defendant performs an action that he should reasonably foresee might advance the cause of the principals (even though he does not intend it to do so)." ${ }_{100}$ On the other hand, Article 30 defines the term "intent" to mean that the "[...] person means to cause [...] [the] consequence or is aware that it will occur in the ordinary course of events." Article 25(3)(d) is arguably the same as the default rule under Article 30. So the inclusion of the term "intentional" in Article $25(3)(\mathrm{d})$ is baffling and is not a sufficient basis from which to derive the criteria for determining whether a member of a transnational terrorist group should be classified as a joint perpetrator or an individual perpetrator on foot of their role in the planning and perpetration of an attack.

An alternative method to the mens rea approach for determining the criteria for classifying a member of a transnational terrorist groups as a joint perpetrator or an individual perpetrator would be to adopt an objective approach by taking into consideration " [...] [the] element of immediacy, of carrying out a task temporally close to the commission of the material elements of the offence." ${ }^{\circ 2}$ Roxin proposed that only the individuals that participated in the commission of the criminal offence after the initial attempt to perpetrate it should be classified as joint co-perpetrators. ${ }^{103}$ Although this approach is compelling it is still problematic because reaching consensus on the definition of an attempt to perpetrate an international crime is difficult. Nevertheless, under the objective approach, the individual's control over the commission of the crime is an essential indicator of joint perpetration. ${ }^{104}$ In general, it is the joint perpetrator who decides "whether and how the offence is actually perpetrated, either by directly taking part in the actus reus or at least by overseeing [...] the commission of the crime by the immediate actors." ${ }^{\text {os }}$ It would be possible to classify the leader of the transnational terrorist group as a joint perpetrator of a terrorist attack where there is evidence to suggest that he or she was in contact with the subordinate members at the location of the attack. This would enable the leader to then decide whether the attempt to carry out the terrorist attack should be abandoned when the subordinates report to him/her that there were unforeseen obstacles. Some transnational terrorist groups because of their network-based structure have developed the capacity to carry out a terrorist attack even if the leader is not in close proximity to the location. Therefore, the approach proposed above could enable the ICC to prosecute a leader of a transnational terrorist group under Article 25(3)(b) of the Rome Statute even if he was not in contact with the subordinate members of the group at the location of the proposed attack by phone because he or she has ordered, solicited, or induced the commission of a crime "which in fact occurs or is attempted."106

Nevertheless, despite the merits of this alternative approach the concept of control advocated by the ICC Pre-Trial Chamber in the Lubanga case is too simplistic when applied to transnational terrorist groups. Instead, a more all-inclusive approach to joint perpetration which comprises both objective and subjective elements is necessary. The paradigm of relevant factors includes the subordinate member's involvement in the planning of the terrorist attacks and his/her own mens rea. Hence, the member's contribution towards the commission of the attacks and the link between his

roo Ohlin, supra n. 30, at 418 .

ror Article 30 of the Rome Statute of the International Criminal Court.

Io2 Ohlin et al., supra n. 49, at 367.

${ }^{103}$ Roxin, supra n. 7, at 25.

${ }^{104}$ Ohlin et al., supra n. 49, at 367.

ros Ibid.

${ }^{106}$ Article 25(3)(b) of the Rome Statute of the International Criminal Court. 
contribution and perpetration of the criminal offence is significant. In any event, it remains a contentious issue whether the ICC should attach greater importance to either objective factors or subjective factors. Perhaps the so-called concept of indirect perpetration may provide a more straightforward approach to prosecuting members of transnational terrorist groups especially in light of their network-based organisational structure?

\section{THE CONCEPT OF INDIRECT CO-PERPETRATORS UNDER ARTICLE 25 AND ITS APPLICATION}

\section{TO MEMBERS OF TRANSNATIONAL TERRORIST GROUPS}

The ICC Pre-Trial Chamber in Prosecutor v. Katanga and Chui combined the doctrine of coperpetration (Mittäterschaft) with the doctrine of indirect perpetration (Täter hinter dem Täter) thereby creating a new controversial mode of liability called the doctrine of indirect co-perpetration (mittelbare Mittäterschaft). ${ }^{107}$ There appears to be no foundation for this new mode of liability in Roxin's control theory of perpetration which made no reference whatsoever to the concept of an indirect co-perpetrator. ${ }^{108}$ Nevertheless, the Pre-Trial Chamber in the Katanga and Chui case described the defendant as an indirect co-perpetrator because he exercised control over an armed group and also collaborated with another defendant, who made a significant contribution to the perpetration of attacks on villages. ${ }^{109}$ Neither the doctrine of indirect perpetration nor the doctrine of co-perpetration could effectively hold both Katanga and Chui accountable because they controlled two distinct armed groups each of which committed substantial elements of the joint criminal endeavour. Due to "ethical loyalties within the respective organizations" the two armed groups could not be merged into a single organization. ${ }^{\text {II }}$ Therefore, there were two distinct armed groups conducting attacks on villages which were fused at the leadership level. ${ }^{\text {II }}$ As a result, the "coordinated essential contribution by each co-perpetrator [...] [resulted] in the realisation of the objective elements of the crime." ${ }^{\prime 12}$

The defence team of Katanga challenged the application of this novel mode of liability. ${ }^{\mathrm{II} 3}$ Their contention was partly supported by the ICTY Trial Chamber's conclusion in Prosecutor v. Milutinović et al. that indirect perpetration was not a mode of liability under customary international

${ }_{107}$ See further Katanga and Chui Confirmation Decision, supra n. 7, at para. 492. In this case, the Pre-Trial Chamber held that: "[r]ather, through a combination of individual responsibility for committing crimes through other persons together with the mutual attribution among the co-perpetrators at the senior level, a mode of liability arises which allows the Court to assess the blameworthiness of 'senior leaders' adequately." For an analysis on the aptness of combining these two modes of liability see T. Weigend, "Perpetration through an Organization: The Unexpected Career of a German Legal Concept" [20II] 9 Journal of International Criminal Justice 9I, at IIO; S. Manacorda and C. Meloni, "Indirect Perpetration versus Joint Criminal Enterprise: Concurring Approaches in the Practice of International Criminal Law?” [20II] 9 Journal of International Criminal Justice 159.

ro8 It is also interesting to note that domestic prosecutions that have relied on the control theory of perpetration did not incorporate this principle of indirect co-perpetration. For examples of these domestic cases see Fujimori Judgment, CSJ, Sala Penal Especial, $7^{\text {th }}$ April 20009, Exp. No. AV 19-200I as referenced in K. Amos, "The Fjimori Judgment: A President's Responsibility for Crimes against humanity as Indirect Perpetrator by Virtue of an Organized Power Apparatus" [20II] 9 Journal of International Criminal Justice 137 , at 147 (footnote 33) and Juntas Trial Case, Judgment of $9^{\text {th }}$ December 1985 , translation reprinted in (1987) 26 International Legal Materials 317 as cited by Olasolo, supra n. 2, at I27-I29.

rog Katanga and Chui Confirmation Decision, supra n. 7, at paras. 543-545.

Io Ibid. at para. 493 .

III Ibid. at para. 548 .

II2 Ibid. at para. 555 .

"I3 Ibid. at para. 474. See also ICC-o1/04-01/06-698 at para. I6. 
law before 1992. ${ }^{\mathrm{II}}$ Nevertheless, the ICC Pre-Trial Chamber in Katanga dismissed this argument by stating that Article 25(3)(a) of the Rome Statute made provision for both indirect perpetration and coperpetration. ${ }^{\text {II }}$ Although, the wording of Article 25 does not make any reference whatsoever to the concept of indirect co-perpetration the Pre-Trial Chamber made the following flimsy argument to support its conclusion:

The Chamber finds that there are no legal grounds for limiting the joint commission of the crime solely to cases in which the perpetrators execute a portion of the crime by exercising direct control over it. Rather, through a combination of individual responsibility for committing crimes through other persons together with the mutual attribution among the co-perpetrators at the senior level, a mode of liability arises which allows the Court to assess the blameworthiness of 'senior leaders' adequately. ${ }^{116}$

Judge Van den Wyngaert, in her concurring opinion in the Chui case ${ }^{\mathrm{II} 7}$ disagreed and concluded that the concept was not a mode of liability under Article 25(3)(a) of the Rome Statute. ${ }^{\mathrm{II}}{ }^{\mathrm{I}}$ Nevertheless, the question whether the indirect co-perpetration of a crime is a mode of liability under Article 25 still persists because many of the recent indictments issued by the ICC, including against Saif al-Islam Gaddafi and Abdullah al-Senussi, have accused them of committing crimes as indirect coperpetrators. ${ }^{119}$ One can understand the appeal of this mode of liability for the prosecution since due to limited resources the ICC has thus far only indicted high-ranking individuals who were generally not present at the scene where the alleged crime took place. By utilising the doctrine of indirect perpetration the prosecution only needs to establish a connection between the accused and the individuals who actually perpetrated the criminal offence.

The foundation for this mode of liability was in the Lubanga case where the Pre-Trial Chamber noted that a co-perpetrator is the individual who exercises "control over the crime." ${ }^{20}$ Under German legal theory, the idea developed that an individual could be held accountable for the indirect perpetration of a crime where he or she exercises control over the individuals who actually perpetrate the crime. ${ }^{\text {I2 }}$ The ICC developed the doctrine of indirect co-perpetration in order to bring individuals to justice more easily for international crimes even if they were not present at the location where the

${ }^{114}$ Prosecutor v. Šainović et al., Decision on Ojdanic's Motion Challenging Jurisdiction: Indirect Co-Perpetration, Case no. IT-05-87, T.Ch., $22^{\text {nd }}$ March 2006 at para. 37.

IIs Katanga and Chui Confirmation Decision, supra n. 7, at para. 49I.

${ }^{116}$ Ibid. at para. 492.

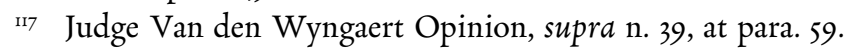

II8 Ibid.

I19 Warrant of Arrest for Saif al-Islam Gaddafi, ICC-oI/II-I4, 27 June 20 II at p. 6, text available at: http://www.icccpi.int/iccdocs/doc/docio99329.pdf, accessed io June 20I3. Warrant of Arrest for Abdullah Al-Senussi, ICC-oI/II-I5, 27 June 2011 at p. 6 text available at: http://www.icc-cpi.int/iccdocs/doc/docio99332.pdf, accessed ro June 20I3. See also Prosecutor v. Francis Kirimi Muthaura and Uburu Muigai Kenyatta, Decision on Confirmation of Charges, Pre-Trial Chamber II, ICCoI/o9-02/II, 23 January 2012; Prosecutor v. William Samoei Ruto and Joshua Arap Sang, Decision on Confirmation of Charges, ICC Appeals Chamber, Case No. ICC-oI/o9-oI/II; Prosecutor v. Omar Hassan Abmad Al Bashir, Decision on Prosecution's Application for a Warrant of Arrest against Omar Hassan Abmad al Bashir, Pre-Trial Chamber I, ICC-02/05oI/o9, 4 March 2009.

${ }_{120}$ Lubanga Decision on Confirmation of Charges, supra n. 7, at para. 340.

${ }^{\text {I2I }}$ This idea was known as "Organisationsherrschaft." See further Roxin, supra n. 7. 
actual perpetrators committed the crime. It is the concept of "control" that links the defendant to the actual perpetrator of the crime and not his proximity to the crime. ${ }^{122}$

This recently developed doctrine is similar to the JCE doctrine developed by the ICTY and could be easily utilised in the prosecution of members of transnational terrorist groups. ${ }^{\mathrm{I} 23}$ It is the highranking members of the group who collaborate together to carry out the terrorist attack and usually do not commit the crime themselves. Instead, it is the subordinate members of the group who carry out the crime under the authority of the high-ranking members. The result is the effective distribution of labour among all members of the transnational terrorist group. The doctrine of indirect co-perpetration ensures that the high-ranking members of the group will be held accountable for their role in the perpetration of the attack. Indeed, in the Katanga and Cbui case the two accused had a joint strategy for their armed groups to effectively conduct attacks on villages. ${ }^{124}$ As a result, the prosecution contended that the defendants were not only responsible for the crimes committed by the members of their own armed groups but also the crimes committed by the other armed group. ${ }^{125}$

However, the Trial Chamber II in its final judgment in the Katanga case dismissed the notion that the modes of liability contained in Article 25 are ordered hierarchically. ${ }^{126}$ It also watered down the test for indirect co-perpetration but in so doing also caused considerable confusion on the construal of Article 25(3). ${ }^{\mathrm{I2}}$ Overall, the judgment constitutes a significant divergence from the past jurisprudence of the court and highlights the need to revisit the interpretation of the Article 25 in the Lubanga Appeal. Judge Van den Wyngaert, in her separate dissenting opinion in the Katanga case dissociated herself from majority's approach on the grounds that it re-categorised the charges against the accused $^{128}$ and repeated her opinion in the Chui case regarding the correct construal of Article $25 .{ }^{129}$ Indeed, Judge Van den Wyngaert stressed that the Majority's rebuff of the hierarchical international Article 25(3)(a) undermined the rationale for importing the control theory of perpetration. ${ }^{130}$

So the application of the doctrine of indirect co-perpetration to members of transnational terrorist groups is not without its challenges. Article 25(3)(a) of the Rome Statute clearly states that a person will be held accountable for perpetrating a crime "jointly with another or through another person" but does not explicitly state that these two modes of liability can be combined. Judge Van den Wyngaert in her Concurring Opinion in the Chui case noted that a literal interpretation of the wording of Article 25(3)(a) of the Rome Statute did not convincingly establish that these modes of liability could be combined together. ${ }^{\mathrm{III}}$ If it did it could lead "to a radical expansion of Article 25(3)(a) of the Statute, and [...] a totally new mode of liability." ${ }_{132}$ Furthermore, Judge Van den Wyngaert further noted that if this interpretation of Article 25(3)(a) was accepted by the Trial Chamber it would be "possible to hold the accused responsible for the conduct of the physical perpetrator of a crime, even though he/she

${ }_{122}$ J. Ohlin, "Second-Order Linking Principles: Combining Vertical and Horizontal Modes of Liability" [2012] 25 Leiden Journal of International Law 771.

${ }^{123}$ Ibid. at 778 .

${ }^{124}$ Katanga and Chui Confirmation Decision, supra n. 7, at para. I9.

${ }^{125}$ Ibid. at para. 484.

${ }^{126}$ Katanga Trial Judgment, supra n. 88, at paras. $\mathrm{I}_{3} 83, \mathrm{I} 384-88$.

I27 Ibid. at paras. 1373, 1384-88 and 1400-I2.

${ }^{128}$ Katanga Trial Judgment (Van den Wyngaert Opinion), supra n. 7. Judge Van den Wyngaert concluded that the Trial Chamber should have rendered its verdict under Article 25(3)(a) and that Katanga should have been acquitted along with Ngudjolo on I8 December 2012.

r29 Ibid. at paras. $279-8 \mathrm{I}$.

r30 Ibid.

I3I Judge Van den Wyngaert Opinion, supra n. 39, at paras. 60 and 64.

${ }^{132}$ Ibid. at para. 6I. 
neither exercised any direct influence or authority over this person, nor shared any intent with him or her." ${ }^{\prime 33}$

Judge Van den Wyngaert examined whether there are any circumstances in which these two modes of liability could be combined despite the wording of Article $25(3)(a) \cdot{ }^{134}$ She held that "different forms of criminal responsibility under the Statute may be combined, as long as all the elements of each form [of liability] are proven." ${ }^{335}$ However, her conclusion that different forms of criminal responsibility can be combined can be challenged because it conflicts with the wording of the Rome Statute. In addition, Judge Van den Wyngaert did not provide a legal basis for her conclusion or discuss the consequences of the Trial Camber adopting this approach. Although high-ranking members of transnational terrorist groups standing trial before the ICC could satisfy the criteria of indirect coperpetration of terrorist attacks because of the manner in which such attacks are planned and perpetrated the doctrine entails much more than the simple combination of the concepts of indirect perpetration and co-perpetration. For example, the Pre-Trial Chamber in the Katanga and Chui Decision Confirmation Decision held that the two accused were only able to perpetrate attacks on villages after the leaders of both groups agreed on a joint strategy to attack villages. ${ }^{136}$ However, the defendants did not fulfil the criteria for both co-perpetration and indirect perpetration. If the defendants had fulfilled the criteria for both forms of liability the application of the doctrine of indirect co-perpetration would have been unnecessary. The prosecution "could simply have selected between co-perpetration and indirect perpetration and could have proceeded with one of these doctrines as their theory of the case." ${ }^{137}$

If the doctrine of indirect perpetration is to be successfully invoked in the prosecution of members of transnational terrorist groups a clear distinction needs to be made between a defendant who held a command position within the group and exercised control over subordinate members and a defendant who exercised control over the transnational terrorist group as an organisation. The ICC has not yet explored whether control over an organisation rather than individual members of an organisation can establish liability under Article 25 of the Rome Statute. The application of the doctrine in this manner could perhaps provide a better basis to hold leaders of transnational terrorist groups accountable for terrorist attacks than the doctrine of command responsibility. Indeed, Article 25(3)(a) can be described as the normative approach to participation in an international crime which provides that the principal is the individual with the most responsibility for the crime because he or she has exercised considerable authority over the commission of the crime even though he may have not played any role in actually committing it.

This is in complete contrast to what Ohlin et al., describes as the "empirical approach to liability" which defines the perpetrator as the individual "who performs the material elements of the offence and this 'perpetrates' or 'commits' the crime." ${ }_{138}$ Under this approach the accessory is the individual "who contributes to causing the actus reus." 39 The "empirical approach to liability" can also be classified as a bottom-up approach to liability. ${ }^{\mathrm{I}+}$ If the empirical approach is applied to a complex organisation such as a transnational terrorist group one can begin with the subordinate member of the

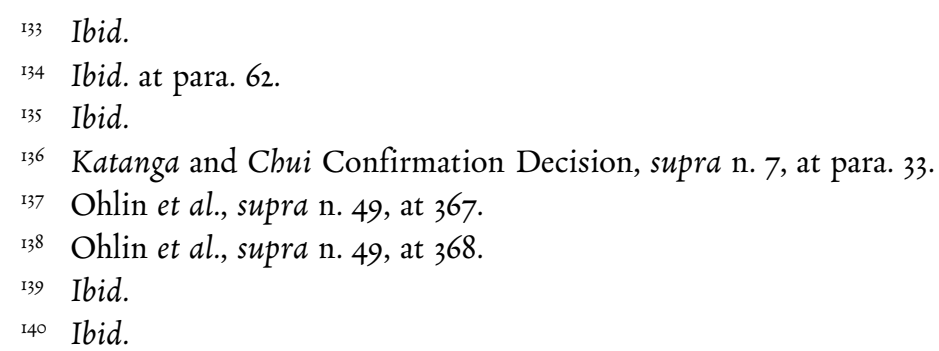


transnational terrorist group who actually carried out the terrorist attack and then move on to the commanders of the group who gave the orders to the subordinate to carry out the attack. On the other hand, the normative approach to criminal participation constitutes a top-down approach to liability where the chain of accountability begins with the commander of the transnational terrorist group who ordered the perpetration of the terrorist attacks and ends with the lowest ranking members of the group.

The ICTY has embraced a normative approach to liability. In the Tadić case, for example, the ICTY Appeals Chamber described JCE as "a form of accomplice liability." "T41 Nevertheless, it utilised the terms "perpetrator" and "co-perpetrator" to describe an individual participating in the JCE. ${ }^{142}$ The judgment of the ICTY Appeals Chamber in the Tadic case led to considerable discussion in the later cases of Prosecutor v. Krsticít3 and Prosecutor v. Kvočka. ${ }^{144}$ In both cases, some judges believed that it was essential to maintain the distinction between the principal and the accomplice. ${ }^{\mathrm{I} 5}$ On the other hand, other members of the judiciary were of the view that such a distinction is irrelevant because it is not until the sentencing stage of the case that the different roles played by the accused becomes important. ${ }^{\mathrm{I} 46}$

Nevertheless, the categorisation of defendants as either principals or accessories has found its footing in the jurisprudence of the ICTY. ${ }^{\mathrm{I} 7}$ For example, in Prosecutor v. Odjanic the majority of the Appeals Chamber held that "joint enterprise is to be regarded, not as a form of accomplice liability, but as a form of commission." ${ }^{148}$ As a result, aiding and abetting has become a mode of liability that is regarded as less culpable than JCE. Indeed, the Appeals Chamber held in Prosecutor v. Šljivančanin that "aiding and abetting is a lower form of liability than ordering, committing, or participating in a joint criminal enterprise and may as such attract a lesser sentence." 149 Empirical research conducted by Hola et al., would support the conclusion that aiding and abetting is considered less culpable by the ad hoc tribunals than other modes of liability. ${ }^{150}$ So the ICTY applies a mitigation principle in relation to aiding and abetting and JCE liability.

This would also appear that a normative approach to liability was applied by the Special Court for Sierra Leone in the Charles Taylor case when he was found guilty of aiding and abetting both crimes against humanity and war crimes. ${ }^{\mathrm{III}}$ It would seem that if Taylor had been convicted for participating in a JCE he would have faced a longer term of imprisonment. Indeed, Judge Lussick held that the prosecution's request that Taylor be sentenced to 80 years imprisonment was excessive as the accused was found guilty of aiding and abetting which "as a mode of liability generally warrants a lesser sentence than that imposed for more direct forms of participation." ${ }^{52}$ Nevertheless, Taylor was

I4I Tadić, supra n. 21, at para. 220.

I42 Ibid.

I43 Krstić, supra n. 6.

144 Prosecutor v. Kvočka, Judgment. Trial Chamber I, IT-98-30/I-T, 2 November 200 (hereinafter Kvočka).

I45 Ibid.

I46 Ibid.

${ }^{147}$ For further academic commentary on this point see C. Damgaard, Individual Criminal Responsibility for Core International Crimes (Springer, New York, 2008), at 198-212 and E. Van Sliedregt, "Joint Criminal Enterprise as a Pathway to Convicting Individuals for Genocide" [2007] 5 Journal of International Criminal Justice I84.

ז48 Prosecutor v. Milutinović et al., Decision on Dragoljub Ojdanić Motion Challenging Jurisdiction - Joint Criminal Enterprise, Pre-Trial Chamber, IT-05-87-PT, 22 March 2006 at para. 20.

${ }_{149}$ Prosecutor v. Šljivančanin, Judgment, Appeals Chamber, IT-95-I3/I-A, 5 May 2009 at para. 407.

sso B. Hola et al., "International Sentencing Facts and Figures: Sentencing Practice at the ICTY and ICTR" [20II] 9 JICJ 4II, at 4I7.

${ }^{151}$ Prosecutor v. Charles Taylor, Judgement, Trial Chamber, SCSL-03-I-T, 26 April 2012 at para. 6959 (hereinafter Taylor).

I52 Ibid. 
sentenced to 50 years imprisonment which in turn illustrates that even though aiding and abetting is recognised as a lower mode of liability it does not necessarily imply that the accused will receive a more lenient prison sentence. ${ }^{\mathrm{I} 3}$

The ICC has arguably embraced the normative approach to participation in an international crime developed by the ICTY. In the Decision on the Confirmation of Charges in the Lubanga case the Pre-Trial Chamber noted that the ICC makes a distinction between principals and accessories and also distinguishes between principal liability in Article 25(3)a) and accessorial liability in Article 25(3)(b-d). ${ }^{154}$ Holding members of transnational terrorist groups accountable under Article 25(3)(a) would signify that they played a significant role in the commission of the offence. ${ }^{155}$ This is in complete contrast to liability under Article 25(3)(b-d) where individuals categorised as accessories are deemed less accountable for the crime. Nevertheless, the application of the normative approach of the control-theory at the ICC has led to considerable controversy. Judge Tarfusser, in his dissenting opinion in the Appeals Decision in the Regulation 55 case in Katanga, noted that Article 25(3) was "far from [...] uncontentious or settled." ${ }_{156}$ This in turn illustrates the impact of the normative approach to participation in a joint criminal endeavour. ${ }^{157}$ Nevertheless, it may still provide an alternative basis to hold leaders of transnational terrorist groups accountable for their role in the commission of a terrorist attack.

\section{(I) Indirect Control of Transnational Terrorist groups under Article 25 of the Rome Statute}

Significant emphasis is attached to organizations under the doctrine of indirect co-perpetration. However, Judge Van den Wyngaert in her Concurring Opinion in the Chui case expressed concern about this recent development stating that Article 25 of the Rome Statute addresses the indirect control over individuals perpetrating atrocities but not indirect control over organizations committing the crimes. ${ }^{158}$ Indeed, she held that "elevating the concept of 'control over an organization' to a constitutive element of criminal responsibility under Article 25(3)(a) is misguided." I59 In particular, she acknowledged that "organisations are made up of persons." ${ }^{160}$ Article 25 only concerns the indirect control of individuals even where this control is exerted by means of an organisation. However, the question still remains as to whether organisations such as transnational terrorist groups can be afforded any special status under the doctrine of indirect co-perpetration because it is the means by which the defendant is alleged to have directed control over the individuals who physically perpetrated the crime. Judge Van den Wyngaert noted that "there is a fundamental difference between the interaction among individuals, even within the context of an organisation, and the exercise of authority over an abstract entity such as an 'organisation." ${ }^{16}$ Consequently, by undermining the relationship between the indirect perpetrator and the actual perpetrator who committed the crime

153 Ibid. at para. 6959.

${ }^{154}$ Lubanga Confirmation Decision, supra n. 7, at paras. 330-335.

${ }_{155}$ Katanga and Ngudjolo Confirmation Decision, supra n. 7, at para. 518.

${ }^{156}$ Prosecutor v. Germain Katanga and Matbieu Ngudjolo Chui, Judgment on the Appeal of Mr. Katanga against the Decision of Trial Chamber II of 2I November 2012 entitled "Decision on the Implementation of Regulation 55 of the Regulations of the Court and Severing Charges against the Accused Persons,” Appeals Chamber, ICC-or/04-0I/07OAI3, 27 March 2013 at para. 15 .

${ }_{157}$ Ohlin et al., supra n. 49, at 368. See also Olasolo, supra n. 2, at 27.

is8 Judge Van den Wyngaert Opinion, supra n. 39, at para. 52.

ז59 Ibid.

160 Ibid. at para. 53 .

161 Ibid. 
"the control over an organisation concept dilutes the level of personal influence that the indirect perpetrator must exercise over the person through whom he or she commits a crime." ${ }^{162}$ As a result, Judge Van den Wyngaert was of the opinion that there was no basis for the concept of the organisation in Article 25 of the Rome Statute.

However, Judge Van den Wyngaert's finding can be challenged. Roxin's theory of control highlights that organisational control is essential to establish liability because it is the subordinate members which carry out the orders of the commander. ${ }^{163}$ If the ICC wants to utilise the doctrine of indirect co-perpetration in the prosecution of members of transnational terrorist groups it needs to develop a principle that explains how the indirect perpetration of a terrorist attack upon a civilian population through a transnational terrorist group is in keeping with the wording of Article 25 and its clear reference to "persons." ${ }^{64}$ One explanation would be that the transnational terrorist group is simply a vessel through which the defendant exercises control over the members of the group who physically perpetrate the attack. Pursuant to this approach, the indirect co-perpetrator can be charged with an offence under the Rome Statute if the offence is committed by another person within the group. In other words, the transnational terrorist group provides the medium through which the indirect co-perpetrator can order the actual perpetrator to carry out the offence. Accordingly, the doctrine of indirect co-perpetration may be an effective mechanism for holding high-ranking members of transnational terrorist groups accountable even if the group is composed of network cells operating without a centralised command. This is because the leader is utilising the organisational structure of the group to his advantage to perpetrate highly coordinated terrorist attacks aimed at the civilian populations in different jurisdictions.

However, this approach is not without significant shortcomings because the ICC in the past has relied on the ambiguous concept of dolus eventualis. Despite the ambiguity whether the concept is akin to recklessness the majority of definitions recognise that the concept means "liability for foreseeing the mere possibility of future events." ${ }^{165}$ The ICTY expanded criminal liability to individuals who did not unequivocally foresee the harmful consequences of his or her conduct by relying on JCE III whereby "a participant [can be] [...] held responsible for any reasonably foreseeable act of any other participant done in furtherance of the joint enterprise." ${ }^{166}$ JCE III permits individuals to be convicted as principals for crimes carried out by co-perpetrators which fall outside the joint criminal plan. In the Lubanga case, the Trial Chamber refused to apply the JCE doctrine instead opting for the control theory of perpetration.

However, an analysis of the doctrine of indirect co-perpetration when liability for dolus eventualis is enforced reveals how similar it is to JCE III liability. ${ }^{\mathrm{I} 7}$ The Pre-Trial Chamber in Prosecutor v. Jean Pierre Bemba Gombo concluded that dolus eventualis "is not captured by Article 30 of the Statute." ${ }^{68}$ It also noted that "[ $t$ ] his conclusion is supported by the express language of the phrase "will occur in the ordinary course of events." "69 However, the Pre-Trial Chamber in the Lubanga case has reached the opposite conclusion and affirmed that dolus eventualis is in keeping with Article 30 of the ICC

162 Ibid.

${ }_{163}$ Roxin, supra n. 7.

${ }^{164}$ See generally Article 25 of the Rome Statute of the International Criminal Court.

165 Ohlin et al., supra n. 49, at 127.

${ }^{166}$ Ibid.

${ }^{167}$ Tadić, supra n. 21, at para. 224.

${ }_{168}$ Prosecutor v. Jean-Pierre Bemba Gombo. Decision Pursuant to Article 6I(7)(a) and (b) of the ICC Statute on the Charges of the Prosecutor against Jean-Pierre Bemba Gombo, ICC-or/05-0I/o8, Pre-Trial Chamber II, I5 June 2009 at para. 360 .

169 Ibid. For a more in-depth analysis of the Pre-Trial Chamber's reasoning for this conclusion see paras. 360 et seq. 
Statute. ${ }^{170}$ Indeed, the Pre-Trial Chamber went as far as to state that when dolus eventualis is combined with the doctrine of indirect co-perpetration it produces a result that is analogous to the JCE III doctrine developed by the ICTY. ${ }^{171}$

So if dolus eventualis is combined with the doctrine of indirect co-perpetration the defendant can be held accountable even if the crimes committed by the transnational terrorist group were not part of the criminal endeavour agreed by the members in command of the group. The Pre-Trial Chamber in the Lubanga case noted that the only restriction in applying the combined dolus eventualis and indirect co-perpetration doctrine is that the accused was "aware of the risk that the objective elements of the crime may result from his or her actions or omissions, and [...] accepts such an outcome by reconciling himself or herself with it or consenting to it [...]." "772 This is in keeping with the reasoning of the ICTY Trial Chamber in Prosecutor v. Milomir Stakić case which affirmed that "[ $t]$ he technical definition of dolus eventualis is the following: if the actor engages in life-endangering behaviour, his [...] [action] becomes intentional if he 'reconciles' himself or 'makes peace' with the likelihood of death." ${ }^{73}$ The Lubanga Pre-Trial Chamber further noted that "if the risk of bringing about the objective elements of the crime is low, the suspect must have clearly or expressly accepted the idea that such objective elements may result from his or her actions or omissions." ${ }^{174}$ Therefore, the subordinate and high-ranking members of the transnational terrorist group can be held accountable under Article 25 of the Rome Statute even if he or she did not want a crime to occur but nevertheless apprehended that such a crime could occur if a terrorist attack was carried out.

At the same time, however, it is unclear whether dolus eventualis is in keeping with the mens rea standard underlying Article 30 of the Rome Statute which states that "unless otherwise provided" the required mental elements of a criminal offence is intent and knowledge. ${ }^{175}$ These two elements necessitate that the consequences of the criminal conduct occur "in the ordinary course of events." ${ }^{176}$ Clark asserts that dolus eventualis is not included in Article $30^{177}$ and has even gone as far as to state that "dolus eventualis and its common law cousin, recklessness, suffered banishment by consensus [during the drafting process] at Rome." ${ }^{178}$ The draft report of the 1996 Preparatory Committee supports Clark's contention ${ }^{179}$ because it initially included a section on dolus eventualis and recklessness which was subsequently deleted. ${ }^{180}$

The ICC would need to thread carefully when applying dolus eventualis to cases involving members of transnational terrorist groups who are accused of being indirect co-perpetrators to ensure that it is in keeping with the fundamental principle of individual criminal responsibility. Some transnational terrorist groups are composed of network cells with no centralised command. In addition, organisational theory on armed groups as propounded by Marighella and Stepanova

${ }^{170}$ Lubanga Confirmation Decision, supra n. 7, at paras. 352-353.

${ }^{171}$ Ibid.

${ }^{172}$ Ibid. at para. 352.

${ }^{173}$ Stakić, supra n. 43 , at para. 587.

${ }^{174}$ Lubanga Confirmation Decision, supra n. 7, at para. 354. The Trial Chamber in Stakić, supra n. 43, at para. 587 stated that "[i]f the killing is committed with 'manifest indifference to the value of human life,' even conduct of minimal risk can qualify as international homicide." See further Stakić, supra n. 43, at para. 587.

${ }^{775}$ Article 30(I) of the Rome Statute of the International Criminal Court.

${ }^{176}$ Article 30(2)(b) of the Rome Statute of the International Criminal Court.

17 R. Clark, "Elements of Crimes in Early Decisions of Pre-Trial Chambers of the International Criminal Court" [2009] New Zealand Y.I.L. 209, at 23r. Professor Schabas has reached a similar conclusion. See Schabas, supra n. 28 , at 476.

${ }_{178}$ Ibid.

${ }^{179}$ Chairman's Text, U.N. Doc. A/AC.249/1997/WG.2/CRP.4.

I80 Ibid. 
illustrates that high ranking members of transnational terrorist groups may be unaware that the subordinate members are planning and perpetrating terrorist attacks outside the nexus of the joint criminal plan. ${ }^{18 \mathrm{I}}$ Therefore, a high-ranking member of a transnational terrorist group who stands accused of being an indirect co-perpetrator could be held responsible under Article 25 for terrorist attacks which he did not actually command or direct. With regard to dolus eventualis the accused does not wish to carry out attacks but does foresee that such acts could cause serious bodily injury and death. It is unclear what this individual's degree of responsibility should be under the Rome Statute. In view of the fact that the doctrine of indirect co-perpetration is not definitively categorised as a mode of liability under the Rome Statute, the ICC needs to ascertain whether such a categorisation is justified.

\section{CONCLUSIONS}

The newly formulated control theory of co-perpetration is an attempt to develop an overall theory of liability at the ICC but is ambiguous in terms of its application and scope to transnational terrorist groups. Since it does not offer any guidance on the limitation of liability under Article 25 of the Rome Statute the foundations of the doctrines of co-perpetration and indirect perpetration are ambiguous. In addition, the concept of "control" under the control-theory of co-perpetration advocated by the ICC Trial Chambers in the Lubanga and the Katanga cases is one-dimensional. As an alternative, a more inclusive approach to joint perpetration which includes both objective and subjective factors would be more appropriate for prosecuting members of transnational terrorist groups. Relevant factors would include the subordinate member's involvement in the planning of the terrorist attacks by the transnational terrorist group and his/her own mens rea and the propinquity of his contribution to the actual perpetration of the criminal offence are also important factors.

A leader can be held responsible for the indirect co-perpetration of an international crime even if he/she did not play any physical role in the commission of the offence or were not at the location where the actual perpetrators committed the crime. It is the concept of "control" that links the defendant to the actual perpetrator of the crime. ${ }^{182}$ However, there seems to be no legal basis for this mode of liability in Roxin's control theory of co-perpetration. Neither can it be inferred from the wording of Article 25 of the Rome Statute. Nevertheless, the ICC Pre-Trial Chamber in the Katanga and Chui case defined the accused as indirect co-perpetrators because they exercised control over armed groups and also collaborated with each other to perpetrate attacks on villages. ${ }^{183}$ If this doctrine is to be applied in prosecutions of members of transnational terrorist groups it needs to make a distinction "between individuals who control distinct organizations but deploy them towards a common cause and individuals who jointly exercise combined authority over a single vertical organization." ${ }^{184}$ The latter would represent a more simplistic application of the doctrine of indirect co-perpetration to one single organisation while the former would institute joint perpetration by means of several organisations. Unfortunately, the ICC has not had the opportunity to examine the

${ }^{18 \mathrm{r}}$ E. Stepanova, Terrorism in Asymmetrical Conflict: Ideological and Structural Aspects (Oxford: Oxford University Press, 2008), at 27. See also: C. Marighella, Mini-Manual of the Urban Guerrilla (Colorado: Paladin Press, I975), at II, I3, I4, 16, 22 and 32 [hereinafter Marighella]. The text of this book is available at: http://www.marxists.org/archive/marighellacarlos/1969/o6/minimanual-urban-guerrilla/>, accessed 5 December 2014.

${ }_{182}$ J. Ohlin, "Second-Order Linking Principles: Combining Vertical and Horizontal Modes of Liability" [2012] 25 Leiden Journal of International Law 771.

r83 Katanga and Chui Confirmation Decision, supra n. 7, at paras. 543-545.

${ }^{184}$ Ibid. 
application of the doctrine of co-perpetration in this manner so it remains to be seen what approach it will adopt.

The ICC also needs to be cautious when applying dolus eventualis in prosecutions of members of transnational terrorist groups who are accused of being indirect co-perpetrators to guarantee that it is in conformity with the fundamental principle of individual criminal responsibility. A member of a transnational terrorist group who stands trial before the ICC on charges of being an indirect coperpetrator could be held responsible for terrorist attacks perpetrated by an organisation which he does not actually command or direct. However, this individual's degree of responsibility under the Rome Statute remains unclear. Since the doctrine of indirect co-perpetration is not definitively categorised as a mode of liability under the Rome Statute, the ICC needs to ascertain whether such a categorisation is justified.

This article has shown there is considerable divergence of opinion among the judiciary at the ICC on the application of Article 25 of the Rome Statute because the concept of control developed by the ICC is not explicitly mentioned in the provision. Yet, despite the ongoing significance of the concept of control in the jurisprudence of the ICC, not many would contest that applying the provision to transnational terrorist groups with a network-based organisational structure would be challenging since it is not always clear who within the group planned and carried out the terrorist attack and thus had control over the crime. In addition, determining whether the leader had control over attacks is also difficult in view of the fact that the subordinate may not have received specific orders to plan and carry out a particular attack and may instead may only have a general instruction to perpetrate an attack whenever the opportunity presents itself. So the efficacy of Article 25 in the prosecution of members of transnational terrorist groups can be challenged. 